\title{
PENEGAKAN HUKUM TERHADAP PENYALAHGUNAAN DAN PENCEGAHAN PENGGUNA NARKOTIKA DI INDONESIA
}

\author{
Oleh : \\ Damar Bastiar \\ Email : damarwiramenggala75@gmail.com \\ Badan Narkotika Nasional (BNN)
}

\begin{abstract}
Abstrak
Penyalahgunaan narkoba masih merupakan masalah kronis yang menimpa Indonesia, kasus peredaran metamfetamin dan banyak pengedar narkoba internasional telah tertangkap dalam beberapa tahun terakhir untuk membuktikan bahwa Indonesia dalam keadaan darurat narkoba. Perdagangan narkoba yang dilakukan dengan teknik canggih telah merambah seluruh Indonesia. Dapat dikatakan bahwa telah terjadi perubahan dalam mode sindikat, di mana jenis-jenis zat psikotropika tertentu tidak lagi diimpor, tetapi distributor mereka lebih suka membuat pabrik untuk memproduksi sendiri. Pengadaan bahan baku, peracikan, hingga perekrutan orang-orang yang terkait dengan pembagian kerja dalam memproduksi obatobatan benar-benar terencana dengan baik. Ini bisa dikatakan ketika melihat tren dalam kasus pabrik narkotika yang terus bermunculan. Kejahatan narkotika telah bersifat transnasional yang dilakukan dengan menggunakan modus operandi tinggi, teknologi canggih, didukung oleh jaringan organisasi yang luas, dan telah menyebabkan banyak korban terutama di kalangan generasi muda yang sangat merugikan kehidupan masyarakat, bangsa, dan kondisi kejahatan.
\end{abstract}

Kata kunci: narkoba, manusia, kejahatan

\begin{abstract}
Drug abuse is still a chronic problem that befell Indonesia, cases of methamphetamine circulation and many international drug dealers have been caught in recent years to prove that Indonesia is in a state of drug emergency. Drug trafficking carried out with sophisticated techniques has penetrated throughout Indonesia. It can be said that there has been a change in the mode of syndicates, where specific types of psychotropic substances are no longer imported, but their distributors prefer to make factories to produce their own. Procurement of raw materials, compounding, until the recruitment of people related to the division of labor in producing drugs is really well planned. This can be said when looking at trends in cases of narcotics factories that continue to emerge. Narcotics crime has been transnational in nature which is carried out using high modus operandi, sophisticated technology, supported by a broad network of organizations, and has caused many victims especially among the younger generation who are very detrimental to the lives of people, the nation, and the state of crime.
\end{abstract}

Keywords: drugs, people, crime 


\section{PENDAHULUAN}

\subsection{Latar Belakang Masalah}

Penyalahgunaan narkotika di Indonesia beberapa tahun terakhir ini menjadi masalah serius dan telah mencapai keadaan yang memprihatinkan, sehingga permasalahan narkoba menjadi masalah nasional. Sebagai salah satu negara berkembang, Indonesia menjadi sasaran yang sangat potensial sebagai tempat pengedaran narkoba secara ilegal. Penyalahgunaan narkoba masih menjadi masalah kronis yang menimpa Indonesia, kasus peredaran sabu dan banyak tertangkapnya bandar-bandar narkoba internasional dalam beberapa tahun terakhir menjadi bukti bahwa Indonesia sedang berada dalam kondisi darurat narkoba.

Peredaran narkoba yang dilakukan dengan teknik canggih telah merambah seluruh Indonesia. Dapat dikatakan terjadi perubahan modus dari para sindikat, dimana khusus jenis psikotropika tidak lagi diimpor namun pengedarnya lebih memilih membuat pabrik untuk memproduksi sendiri. Pengadaan bahan baku, peracikan, hingga perekrutan orang terkait pembagian tugas dalam memproduksi narkoba benarbenar direncanakan dengan baik. Hal ini dapat dikatakan ketika melihat tren kasus pabrik-pabrik narkotik yang terus bermunculan. Tindak pidana narkotika telah bersifat transnasional yang dilakukan dengan menggunakan modus operandi yang tinggi, teknologi yang canggih, didukung oleh jaringan organisasi yang luas, dan sudah banyak menimbulkan korban terutama di kalangan generasi muda yang sangat merugikan kehidupan masyarakat, bangsa, dan negara.

Indonesia yang pada mulanya sebagai Negara transit perdagangan narkoba, kini sudah dijadikan daerah tujuan operasi oleh jaringan Narkoba Internasional. Tingginya angka penyalahgunaan narkoba tersebut juga disumbang oleh ulah pada sindikat narkoba. Sebagian besar penyalahgunaan berada pada kelompok coba pakai terutama pada kelompok pekerja. Alasan penggunaan Narkoba karena pekerjaan yang berat, kemampuan sosial ekonomi, dan tekanan lingkungan teman kerja merupakan faktor pencetus terjadinya penyalahgunaan Narkoba pada kelompok pekerja.

Tindak pidana narkotika dalam Undang-Undang No. 35 Tahun 2009 tentang Narkotika memberikan sanksi pidana yang cukup berat, namun demikian dalam kenyataannya para pelaku kejahatan justru semakin meningkat, dan bagi para terpidana dalam kenyataannya tidak jera dan justru ada kecenderungan untuk mengulanginya lagi. Hal ini dapat diakibatkan oleh adanya faktor penjatuhan 
pidana yang tidak memberikan dampak atau deterrent effect terhadap para pelakunya.

\subsection{Perumusan Masalah}

Berdasarkan latar belakang yang telah dipaparkan di atas, maka permasalahan yang akan diteliti dapat dirumuskan sebagai berikut :

1. Apa bentuk peran pemerintah Indonesia dalam menekan peredaran dan penyalagunaan narkoba di Indonesia?

2. Bagaimana upaya penyembuhan terhadap korban akibat atas penyalagunaan peredaran narkoba di masyarakat?

\section{METODE PENELITIAN}

Tulisan ini menggunakan metode penelitian hukum normatif, yaitu meneliti hukum dari perspektif internal dengan objek penelitiannya adalah norma hukum. Dengan kata lain penelitian hukum yang meletakkan hukum sebagai sebuah bangunan sistem norma. Sistem norma yang dimaksud adalah mengenai asas-asas, norma, kaidah dari peraturan perundangan, putusan pengadilan, perjanjian serta doktrin (ajaran). ${ }^{1}$

1 I Made Pasek Diantha, 2016, Metodologi Penelitian Hukum Normatif dalam Justifikasi Teori Hukum (Jakarta : Prenada Media Grup). hlm 12
Pendekatan yang digunakan adalah pendekatan perundang-undangan dan pendekatan konseptual. Pendekatan perundang-undangan atau statute approach digunakan jika permasalahan penelitiannya mempermasalahkan konflik norma yang terjadi secara vertikal maupun horizontal. Dalam setiap penelitian atau survei terhadap sesuatu masalah dapatlah digunakan bermacam-macam cara atau metode seperti melakukan penelitian atau survei secara kepustakaan, melakukan interview dan sebagainya.

Pendekatan konseptual atau conceptual approach beranjak dari pandangan-pandangan dan doktrin-doktrin yang berkembang di dalam ilmu hukum, sehingga dapat menemukan ide-ide yang melahirkan pengertian-pengertian hukum, konsep-konsep hukum, dan asas-asas hukum yang relevan dengan isu yang dihadapi. $^{2}$

\section{HASIL DAN PEMBAHASAN}

\subsection{Bentuk Peran Pemerintah Dalam Menekan Peredaran Dan Penyalagunaan Narkotika Di Indonesia}

Narkoba adalah singkatan dari narkotika, psikotropika dan bahan adiktif lainnya. Narkoba adalah obat, bahan, atau

${ }^{2}$ Ibid, hlm. 159 
zat dan bukan tergolong makanan jika diminum, diisap, dihirup, ditelan atau disuntikkan, berpengaruh terutama pada kerja otak (susunan syaraf pusat), dan sering menyebabkan ketergantungan. Akibatnya kerja otak berubah (meningkat atau menurun), demikian juga fungsi vital organ tubuh lain (jantung, peredaran darah, pernapasan dan lainnya). Sesuai dengan Undang-Undang Narkoba Nomor 35 Tahun 2009 tentang Narkotika. Narkoba dibagi dalam 3 jenis yaitu Narkotika, Psikotropika dan Zat adiktif lainnya.

Narkotika golongan I, adalah narkotika yang paling berbahaya. Daya adiktifnya sangat tinggi. Golongan ini digunakan untuk penelitian dan ilmu pengetahuan. Contoh : ganja, heroin, kokain, morfin, dan opium. Narkotika golongan II, adalah narkotika yang memiliki daya adiktif kuat, tetapi bermanfaat untuk pengobatan dan penelitian. Contoh : petidin, benzetidin, dan betametadol. Narkotika golongan III, adalah narkotika yang memiliki daya adiktif ringan, tetapi bermanfaat untuk pengobatan dan penelitian. Contoh: kodein dan turunannya.

Pengertian Psikotopika adalah zat atau obat bukan narkotika, baik alamiah maupun sintesis, yang memiliki khasiat psikoaktif melalui pengaruh selektif pada susunan saraf pusat yang menyebabkan perubahan khas pada aktivitas normal dan perilaku. Psikotropika digolongkan lagi menjadi 4 kelompok adalah :

Psikotropika golongan I, adalah dengan daya adiktif yang sangat kuat, belum diketahui manfaatnya untuk pengobatan dan sedang diteliti khasiatnya. Contoh: MDMA, LSD, STP, dan ekstasi. Psikotropika golongan II, adalah psikotropika dengan daya adiktif kuat serta berguna untuk pengobatan dan penelitian. Contoh : amfetamin, metamfetamin, dan metakualon. Psikotropika golongan III, adalah psikotropika dengan daya adiksi sedang serta berguna untuk pengobatan dan penelitian. Contoh : lumibal, buprenorsina, dan fleenitrazepam. Psikotropika golongan IV, adalah psikotropika yang memiliki daya adiktif ringan serta berguna untuk pengobatan dan penelitian. Contoh : nitrazepam (BK, mogadon, dumolid) dan diazepam.

Zat adiktif lainnya adalah zat-zat selain narkotika dan psikotropika yang dapat menimbulkan ketergantungan pada pemakainya, diantaranya adalah ${ }^{3}$ :

a. Rokok

b. Kelompok alkohol dan minuman lain yang memabukkan dan menimbulkan ketagihan.

c. Thiner dan zat lainnya, seperti lem kayu, penghapus cair dan aseton, cat, bensin

${ }^{3}$ Alifia, U, 2008, Apa Itu Narkotika dan Napza, Semarang: PT Bengawan Ilmu, hal. 25. 
yang bila dihirup akan dapat memabukkan.

Peredaran narkoba di Indonesia kondisinya sudah mengkhawatirkan. Hal ini berdasarkan data yang dikeluarkan oleh Polri dimana angka kasus peredaran narkoba di Indonesia mengalami peningkatan sebagai berikut: pada tahun 2010 jumlah kasus narkoba berjumlah 17.384 kasus dengan jumlah tersangka sebesar 23.900; pada tahun 2011 terjadi peningkatan kasus menjadi sebanyak 19.045 dengan jumlah tersangka sebanyak 25.154; pada tahun 2012 jumlah kasus sebesar 18.977 dengan jumlah tersangka sebanyak 25.122; pada tahun 2013 berjumlah 21.119 kasus dengan total 28.543 tersangka; serta pada tahun 2014 terdapat sebesar 22.750 kasus dengan jumlah tersangka sebanyak 30.496 .

Maraknya peredaran narkoba di Indonesia dikarenakan banyaknya pelabuhan tidak resmi atau biasa dikenal dengan pelabuhan tikus yang dijadikan sebagai tempat favorit bagi pelaku pengedar narkoba. Terdapat beberapa cara yang dilakukan oleh pelaku dalam melakukan transaksi narkoba, antara lain yaitu face to face, transaksi melalui kurir, pembelian langsung ke lokasi peredaran narkoba, sistem tempel (sistem tanam ranjau), serta sistem lempar lembing. Sumber narkoba yang beredar di Indonesia kebanyakan berasal dari luar negeri seperti Asia, Eropa, Afrika dan Amerika.

Terdapat berbagai cara bagaimana narkoba dapat masuk ke wilayah Indonesia. Ada yang masuk ke Indonesia langsung dari negara asalnya, ada pula yang masuk ke Indonesia dengan cara transit lebih dulu ke Malaysia, untuk kemudian dibawa ke Indonesia. Jalur yang ditempuh dari negara transit ini juga bermacam-macam. Bisa melalui jalur udara, jalur laut, sungai, maupun dari darat melalui wilayah perbatasan. Jalur laut dan jalur sungai paling banyak dimanfaatkan oleh pelaku untuk didistribusikan ke berbagai wilayah, dikarenakan banyaknya pelabuhan kecil yang tersebar di berbagai provinsi (Kalimantan, Sumatera, dan Papua) serta kurangnya pengawasan oleh aparat di daerah tersebut. ${ }^{4}$ Kurangnya sumber daya manusia serta sarana prasarana yang kurang memadai menjadi faktor lemahnya pengawasan terhadap jalur laut dan sungai.

Pencegahan atau penanggulangan penyalahgunaan narkoba merupakan suatu upaya yang ditempuh dalam rangka penegakan baik terhadap pemakaian, produksi maupun peredaran gelap narkotika yang dapat dilakukan oleh setiap orang baik individu, masyarakat.

\footnotetext{
${ }^{4}$ Apriliantin Putri Pamungkas, 2017“"Peran ASEANAPOL dalam Pemberantasan Peredaran Narkoba di Indonesia", Journal of International Relations, Volume 3, Nomor 2, , url: http://ejournals1.undip.ac.id/index.php/jihi, hal. 93
} 
Pengertian kepolisian terdapat dalam Undang-Undang di Indonesia. Undang-undang yang membahas tentang Kepolisian Negara Republik Indonesia terdapat dalam Undang-Undang No 2 Tahun 2002 dalam Pasal 1 ayat (1). Dalam Undang-Undang Nomor 2 Tahun 2002 Pasal 1 ayat (1) menyebutkan bahwa "Kepolisian adalah segala hal-ihwal yang berkaitan dengan fungsi dan lembaga polisi sesuai dengan peraturan perundangundangan; Anggota Kepolisian Negara Republik Indonesia adalah pegawai negeri pada Kepolisian Negara Republik Indonesia. Fungsi kepolisian sebagai salah satu fungsi pemerintahan negara di bidang pemeliharaan keamanan dan ketertiban masyarakat, penegakan hukum, pelindung, pengayom dan pelayanan kepada masyarakat. Sedangkan lembaga kepolisian adalah organ pemerintah yang ditetapkan sebagai suatu lembaga dan diberikan kewenangan menjalankan fungsinya berdasarkan peraturan perundangundangan. Polri dalam upaya pencegahan dan penanggulangan penyalahgunaan narkoba, melakukan langkah strategis sebagai berikut:

a. Pre-emptif

Upaya pre-emptif yang dilakukan adalah berupa kegiatan-kegiatan edukatif (pendidikan/pengajaran) dengan tujuan mempengaruhi faktor-faktor penyebab yang mendorong dan faktor peluang, yang biasa disebut faktor "korelatif kriminologen" dari kejahatan narkotika, sehingga tercipta suatu kesadaran, kewaspadaan, daya tangkal, serta terbina dan terciptanya kondisi perilaku/norma hidup bebas Narkoba. Yaitu dengan sikap tegas untuk menolak terhadap kejahatan Narkoba. Kegiatan ini pada dasarnya berupa pembinaan dan pengembangan lingkungan pola hidup sederhana dan kegiatan positif, terutama bagi remaja dengan kegiatan yang bersifat produktif, konstraktif, dan kreatif. Sedangkan kegiatan yang bersifat preventif edukatif dilakukan dengan metode komunikasi informasi edukatif, yang dilakukan melalui berbagai jalur antara lain keluarga, pendidikan, lembaga keagamaan, dan organisasi kemasyarakatan.

\section{b. Preventif}

Upaya ini dilakukan untuk mencegah terjadinya kejahatan Narkoba melalui pengendalian dan pengawasan jalur resmi serta pengawasan langsung terhadap jalur-jalur peredaran gelap dengan tujuan agar Police Hazard tidak berkembang menjadi ancaman faktual.

\section{c. Represif}

Upaya Represif atau penindakan dilakukan dengan cara melakukan penangkapan- penangkapan terhadap para pengguna dan pengedar narkoba. Penangkapan tidak hanya dilakukan 
terhadap warga negara Indonesia saja, tetapi penangkapan juga dilakukan terhadap warga negara asing yang terlibat.

Badan Narkotika Nasional (BNN) adalah lembaga pemerintah non kementerian yang berkedudukan di bawah dan bertanggung jawab kepada Presiden melalui koordinasi Kepala Kepolisian Negara Republik Indonesia. Dalam melaksanakan tugas pemberantasan penyalahgunaan dan peredaran gelap Narkotika dan Prekursor Narkotika, Badan Narkotika Nasional berwenang melakukan penyelidikan dan penyidikan penyalahgunaan dan peredaran gelap narkotika dan prekursor narkotika. Badan Narkotika Nasional (BNN) juga bertugas menyusun dan melaksanakan kebijakan nasional mengenai pencegahan dan pemberantasan penyalahgunaan dan peredaran gelap psikotropika, prekursor, dan bahan adiktif lainnya kecuali bahan adiktif untuk tembakau dan alkohol.

Dalam melaksanakan tugas pemberantasan penyalahgunaan dan peredaran gelap Narkotika dan Prekursor Narkotika, Badan Narkotika Nasional (BNN) berwenang melakukan penyelidikan dan penyidikan penyalahgunaan dan peredaran gelap Narkotika dan Prekursor Narkotika. Keberadaan badan narkotika nasional sesuai dengan Keppres RI No.17/2002 tanggal 22 Maret 2002, dalam rangka penanggulangan dan pemberantasan peredaran gelap narkotika, kiranya harus lebih aktif mengkoordinasikan instansi pemerintah terkait dalam penyusunan kebijakan dan pelaksanaan dibidang ketersediaan, pencegahan dan pem-berantasan penyalahgunaan dan peredaran gelap narkotika, psikotropika, precursor dan aditif lainnya.

Tugas Badan Narkotika Nasional (BNN) disebut dalam Pasal 70 UndangUndang 39 tahun 2009 dan Pasal 2 Perpres No. 23 tahun 2010, sebagai berikut:

a. Menyusun dan melaksanakan kebijakan nasional mengenai pencegahan dan pemberantasan penyalahgunaan dan peredaran gelap narkotika dan prekursor narkotika.

b. Mencegah dan memberantas penyalahgunaan dan peredaran gelap narkotika dan prekursor narkotika.

c. Berkoordinasi dengan Kepala Kepolisian Republik Negara Indonesia dalam pencegahan dan pemberantasan penyalahgunaan dan peredaran gelap narkotika dan prekursor narkotika.

d. Meningkatkan kemampuan lembaga rehabilitasi medis dan rehabilitasi sosial pecandu narkotika, baik yang diselenggarakan oleh pemerintah maupun masyarakat.

e. Memberdayakan masyarakat dalam pecegahan penyalahgunaan dan peredaran gelap narkotika dan prekursor narkotika.

f. Memantau, mengarahkan, dan me- 
ningkatkan kegiatan masyarakat dalam pencegahan penyalahgunaan dan peredaran gelap narkotika dan prekursor narkotika.

g. Melakukan kerja sama bilateral dan multirateral, baik regional maupun internasional, guna mencegah dan memberantas peredaran gelap narkotika dan prekursor narkotika.

h. Mengembangkan laboratorium narkotika dan prekursor narkotika.

i. Melaksanakan administrasi penyelidikan dan penyidikan terhadap perkara penyalahgunaan dan peredaran gelap narkotika dan prekursor narkotika.

j. Membuat laporan tahunan mengenai pelaksanaan tugas dan wewenang.

Dalam rangka melakukan upaya pencegahan, pemberantasan dan penanggulangan penyalahgunaan dan peredaran gelap narkotika lintas negara, perlu digunakan pendekatan multi dimensional dengan memanfaatkan berbagai disiplin ilmu pengetahuan dari penerapan teknologi. Sebagaimana diungkapkan oleh Wijaya, mengatakan bahwa penanggulangan terhadap peredaran gelap dan penyalahgunaan narkotika dapat di tempuh melalui berbagai strategi dan kebijakan pemerintah yang kemudian dilaksanakan secara menyeluruh dan simultan oleh aparat terkait bekerjasama dengan komponen masyarakat anti narkoba. ${ }^{5}$ Adapun strategi penanggulangan terhadap peredaran gelap dan penyalahgunaan narkoba adalah sebagai berikut:

a. Strategi Pengurangan Permintaan (Demand Reduction) Narkoba

b. Strategi pengurangan permintaan meliputi pencegahan penyalahgunaan narkoba. Upaya ini meliputi:

c. Primer atau pencegahan dini. Yaitu ditujukkan kepada individu, keluarga atau komunitas dan masyarakat yang belum tersentuh oleh permasalahan penyalahgunaan dan peredaran gelap narkoba, dengan tujuan membuat individu, keluarga, dan kelompok untuk menolak dan melawan narkoba.

d. Pencegahan sekunder atau pencegahan kerawanan.

Yaitu ditujukan kepada kelompok atau komunitas yang rawan terhadap penyalahgunaan narkoba. Pencegahan ini dilakukan melalui jalur pendidikan, konseling, dan pelatihan agar mereka berhenti, kemudian melakukan kegiatan positif dan menjaga agar mereka tetap lebih mengutamakan kesehatan.

\footnotetext{
${ }^{5}$ Wijaya, Wagimin Wira, 2005, Jurnal Intelijen \& Kontra Intelijen volume II/No.07 url:https://media.neliti.com/media/publications/ 187604-ID.
} 
e. Pencegahan tertier

Yaitu pencegahan terhadap para pengguna/pecandu kambuhan yang telah mengikuti program teraphi dan rehabilitas, agar tidak kambuh lagi.

f. Pengawasan Sediaan (Supply Control) Narkoba

g. Pengawasan Jalur Legal Narkoba

h. Narkoba dan prekusor untuk keperluan medis dan ilmu pengetahuan serta untuk keperluan industri diawasi oleh pemerintah.Pengawasan jalur legal ini meliputi pengawasan penanaman, produksi, importasi, eksportasi, transportasi penggudangan, distribusi dan penyampaian oleh instansi terkait, dalam hal ini departemen kehutanan.

i. Pengawasan Jalur Ilegal Narkoba

j. Pengawasan jalur ilegal narkoba meliputi pencegahan di darat, di laut dan di udara. Badan narkotika nasional telah membentuk Airport dan seaport interdiction task force (satuan tugas pencegahan pada kawasan pelabuhan udara dan pelabuhan laut).

Pengurangan Dampak Buruk (Harm Reduction) Penyalahgunaan Narkoba. Sampai saat ini pemerintah secara resmi hanya mengakui dan menjalankan dua strategi yaitu pengurangan permintaan dan pengawasan sediaan narkoba. Namun menghadapi tingginya prevalensi OHD (orang dengan HIV/AIDS) dikalangan penyalahgunaan narkoba dengan jarum suntik secara bergantian, maka pada 8 Desember 2003 BNN telah mengadakan nota kesepahaman dengan KPA (komisi penanggulangan HIV/AIDS), nomor 21 kep/menko/kesra/XII/BNN, yang bertujuan untuk membangin kerjasama antara komisi penganggulangan AIDS (KPA) dengan $\mathrm{BNN}$ dalam rangka pencegahan penyebaran HIV/AIDS dalam pemberantasan penyalahgunaan narkotika.

\subsection{Upaya Penyembuhan Terhadap Korban Atas Peredaran} Penyalagunaan Narkoba Di Masyarakat

Pelaksanaan Undang Undang Nomor 35 Tahun 2009 Tentang Narkotika mengamanatkan kepada masyarakat, khususnya para penegak hukum untuk menangani penyalahgunaan narkotika agar menjamin upaya pengaturan rehabilitasi medis dan rehabilitasi sosial bagi penyalah guna dan pecandu narkotika. Amanat undang Undang tadi secara khusus diberikan kepada para hakim yang memeriksa dan mengadili perkara penyalah guna narkotika (tersangka penyalah guna dan dalam keadaan yang sangat ketergantungan).

Kepada tersangka penyalah guna narkotika yang terbukti bersalah, hakim dapat memutuskan memerintahkan yang bersangkutan menjalani rehabilitasi. Begitu pula kepada tersangka penyalah guna 
narkotika yang tidak terbukti bersalah, hakim dapat menetapkan untuk memerintahkan yang bersangkutan menjalani rehabilitasi. Hukuman rehabilitasi merupakan hukuman paling tepat bagi penyalah guna narkotika yang bermasalah dengan hukum sebagai alternatif atau pengganti hukuman, dimana penyalah guna narkotika harus menjalani tindakan perawatan, pendidikan, after care, rehabilitasi dan re-integrasi sosial (Pasal 36 Undang-Undang 8/1976 tentang Pengesahan Konvensi Tunggal Narkotika 1961 beserta Protokol yang mengubahnya). ${ }^{6}$

Masa menjalani rehabilitasi pun diperhitungkan sebagai masa menjalani hukuman (103 ayat 2 Undang-Undang 35/2009). Hal tersebut merupakan amanat Undang-Undang 8/1976 tentang Pengesahan Konvensi Tunggal Narkotika dan Protokol yang mengubahnya dan Undang-Undang 7/1997 tentang Pengesahan United Nation Convention Againts Illicit Traffic In Narcotic Drugs And Psycotropic Substances 1988, dan telah diterjemahkan dalam pasal 4 huruf (d) Undang-Undang No 35 Tahun 2009 Tentang Narkotika yang menjiwai sejumlah pasal didalamnya.

Dalam sistem hukum pidana Indonesia, khususnya undang-undang

6 Hawari, D. 2002. Penyalahgunaan \& Ketergantungan NAZA, Jakarta: FKUI. narkotika, baik mengedarkan, menjual, membawa, menyimpan maupun mengkonsumsi tanpa izin dari pihak yang berwenang adalah termasuk dalam kategori pelaku pelanggar hukum. Kategori-kategori tadi sudah diatur dalam Undang-Undang No 35 Tahun 2009 Tentang Narkotika. Dalam Undang-Undang No 35 Tahun 2009 Tentang Narkotika itu pelakunya dikategorikan menjadi dua kelompok, yaitu sebagai "pengedar" dan sebagai "pemakai". Pada Undang-Undang No 35 Tahun 2009 Tentang Narkotika secara eksplisit tidak dijelaskan pengertian "pengedar narkotika". Namun, secara imlisit dan sempit bahwa pengedar dapat dikatakan orang yang melakukan kegiatan penyaluran dan penyerahan narkotika.

Akan tetapi secara luas, pengertian pengedar narkotika mencakup pada dimensi menjual, pembeli untuk diedarkan, dan meliputi menyimpan, menguasai menyediakan melakukan kegiatan mengekspor dan mengimpor narkotika. ${ }^{7}$ Hal itu disebutkan dalam ketentuan pada Pasal 111, 112, 112, 114, 115, 116, 117, $118,119,120,121,122,123,124$, dan 125 UNDANG-UNDANG No 35 Tahun 2009 Tentang Narkotika. Sementara sebutan

7 Mas Candra Dewi, A.A.I, 2012. Perlindungan Hukum Terhadap Korban Penyalahguna Narkotika Dengan Berlakunya Undang Undang No 35 Tahun 2009 Tentang Narkotika, Jurnal Program Studi Magister Hukum Program Magister. Bali: Program Pascasarjana Universitas Udayana. 
dalam kategori pengguna narkotika adalah orang yang menggunakan zat atau obat yang berasal dari tanaman baik sintesis maupun semi sintesis yang dapat menyebabkan penurunan atau perubahan kesadaran, hilangnya rasa nyeri dan dapat menimbulkan ketergantungan, yang dibedakan dalam golongan-golongan sebagaimana terlampir dalam Pasal 116, 121, 126, 127,128, dan 134 dalam UndangUndang No 35 Tahun 2009 Tentang Narkotika.

Pada prakteknya, pecandu narkoba merupakan "self victimizing victim" yaitu mereka yang menjadi korban karena kejahatan yang dilakukannya sendiri. Karena pecandu narkotika mendrita sindrom ketergantungan akibat dari penyalahgunaan narkotika yang dilakukannya sendiri. Namun, pecandu tadi diharapkan mendapat perlindungan agar dirinya dapat menjadi lebih baik lagi.

Pelaksanaan rehabilitasi bagi pecandu narkoba sebagai pengganti dari sanksi hukuman yang bersifat kurungan pinjara diadopsi dari model doble track system, yaitu yang merupakan sistem dua jalur mengenai sanksi dalam hukuman pidana, yakni jenis sanksi pidana dan jenis sanksi tindakan. Artinya, fokus sanksi pidana ditujukan pada perbuatan salah yang telah dilakukan seseorang melalui pengenaan penderitaan agar yang bersangkutan menjadi jera. Sementara fokus sanksi tindakan lebih terarah kepada upaya pemberian pertolongan pada pelaku agar dia berubah. Dalam arti lain, bahwa sanksi pidana bertujuan pada pembalasan terhadap si pelaku, sedangkan sanksi tindakan bertujuan untuk memberi perlindungan, perawatan dan pembinaan kepada masyarakat, khususnya bagi pecandu narkotika.

Jaminan perlindungan hukum yang diberikan bagi pecandu narkotika diatur melalui Undang-Undang No 35 Tahun 2009 Tentang Narkotika dengan memberikan rehabilitasi baik medis maupun rehabilitasi sosial sebagaimana tercantum pada Pasal 54 pada undang-undang narkotika itu. Yaitu bahwa "pecandu narkotika dan pecandu penyalahguna narkotika wajib menjalani rehabilitasi medis dan rehabilitasi sosial”.

Kebijakan pemerintah atas perlindungan dan pembinaan terhadap pecandu narkotika didukung oleh terbitnya Surat Edaran Mahkamah Agung Nomor 4 Tahun 2010 agar menjadi pegangan para penegak hukum dalam sistem peradilan pidana, khususnya pertimbangan pada hakim. Pembinaan terhadap pecandu narkoba didukung oleh terbitnya Peraturan Pemerintah Nomor 25 Tahun 2011 Tentang Pelaksanaan Wajib Lapor Pecandu Narkotika. Tujuannya, agar para pecandu narkotika tadi tidak takut untuk melaporkan dirinya ke Institusi Penerima Wajib Lapor (IPWL) yang telah ditunjuk pemerintah, 
karena dengan payung hukum Pasal 54 dan 103 ayat (1) para pecandu narkotika tidak akan dijebloskan ke dalam penjara jika terbukti hanya mengkonsumsi narkotika dan akan mendapatkan layanan rehabilitasi.

Dengan adanya kebijakan pemerintah akan wajib lapor diharapkan lebih banyak menarik kesadaran pecandu dan keluarganya untuk melaporkan diri atau anggota keluarga mereka yang pecandu sehingga semakin banyak pula pecandu menerima perawatan di pusat- pusat rehabilitasi yang ditunjuk pemerintah seperti puskesmas, rumah sakit-rumah sakit yang termasuk kategori IPWL. Dengan demikian, dengan diimplementasikannya kebijakan atau program kriminal pemerintah tadi, diharapkan akan semakin sedikit jumlah pecandu yang diputus oleh pengadilan.

Namun, jika mengacu kepada kebijakan pemerintah tadi dan dibandingkan dengan jumlah pemakai narkoba di negeri ini, yaitu mencapai 5,1 juta jiwa orang, maka akan terlihat kerancuan dan inkonsistensi dalam pelaksanaannya. Indikasi itu terlihat dari penaganan terhadap pecandu narkoba di lapangan, diantaranya:

Pertama, lembaga pemasyarakata (Lapas) di Indonesia banyak dihuni oleh kasus pelaku narkoba. Mememang, kondisi banyaknya penghuni Lapas karena narkoba perlu di klasifikasikan antara pecandu, kurir, pengedar atau bandar narkoba. Tapi, jika melihat regulasi terkait narkoba itu, sebagaimana menurut Undang-Undang No 35 Tahun 2009 Tentang Narkotika, pecandu narkoba harusnya mendapatkan rehabilitasi bukan di tahan berlama-lama di Lapas.

Kedua, indikasi lain yang terlihat atas inkonsistensi pemerintas dalam pelaksanaan Undang-Undang No 35 Tahun 2009 Tentang Narkotika adalah diperkirakan tidak meratanya atau sebandingnya jumlah IPWL di berbagai daerah dengan jumlah pecandu narkotika. Padahal pecandu narkotika hampir merata diseluruh penjuru wilayah.

Ketiga, pelaksanaan dekriminalisasi berupa pecandu narkoba mendapatkan rehabilitasi baik medis maupun rehabilitasi sosial, masih belum seluruhnya dipahami masyarakat, khususnya masyarakat yang belum sadar atau melek hukum. Sehingga mendorong rasa takut dan kekawatiran bagi yang malapor. Karena, dalam anggapan masyarakat berurusan hukum sangat menyita waktu dan rumit dan perlu keahlian tersendiri.

Keempat, pecandu narkoba atau terlibat narkoba masih dipandang aib atau cela oleh sebagian besar masyarat. Kelima, akses masyarakat terhadap pusat-pusat atau kantor hukum belum merata. Artinya, akses kepada kantor polisi atau instansi IPWL tadi tidak semudah sebagaimana akses di perkotaan atau kota-kota besar, yaitu relatif 
sangat mudah terjangkau, transfortasi yang mudah terjangkau dan imprstruktur yang relatif lebih baik dibanding daerah-daerah lain di wilayah Negara Kesatuan Republik Indonesia.

Dengan adanya lima hal tadi, maka kebijakan pemerintah dalam menanggulangi pecandu narkotika tidak sepenuhnya terlaksana sebagaimana amanah Undang-Undang No 35 Tahun 2009 Tentang Narkotika yaitu memberikan pembinaan, perawatan terhadap pecandu narkotika. Artinya, pemerintah masih belum konsisten alias inkonsistensi dalam melaksanakan Undang-Undang No 35 Tahun 2009 Tentang Narkotika.

\section{KESIMPULAN}

1. Narkoba adalah singkatan dari narkotika, psikotropika dan bahan adiktif lainnya. Narkoba adalah obat, bahan, atau zat dan bukan tergolong makanan jika diminum, diisap, dihirup, ditelan atau disuntikkan, berpengaruh terutama pada kerja otak (susunan syaraf pusat), dan sering menyebabkan ketergantungan. Akibatnya kerja otak berubah (meningkat atau menurun), demikian juga fungsi vital organ tubuh lain (jantung, peredaran darah, pernapasan dan lainnya). Sesuai dengan Undang-Undang Narkoba Nomor 35 Tahun 2009 tentang Narkotika. Narkoba dibagi dalam 3 jenis yaitu Narkotika, Psikotropika dan Zat adiktif lainnya. Pengurangan Dampak Buruk (Harm

Reduction) Penyalahgunaan Narkoba. Sampai saat ini pemerintah secara resmi hanya mengakui dan menjalankan dua strategi yaitu pengurangan permintaan dan pengawasan sediaan narkoba.

2. Pelaksanaan rehabilitasi bagi pecandu narkoba sebagai pengganti dari sanksi hukuman yang bersifat kurungan pinjara diadopsi dari model double track system, yaitu yang merupakan sistem dua jalur mengenai sanksi dalam hukuman pidana, yakni jenis sanksi pidana dan jenis sanksi tindakan. Artinya, fokus sanksi pidana ditujukan pada perbuatan salah yang telah dilakukan seseorang melalui pengenaan penderitaan agar yang bersangkutan menjadi jera. Sementara fokus sanksi tindakan lebih terarah kepada upaya pemberian pertolongan pada pelaku agar dia berubah. Dalam arti lain, bahwa sanksi pidana bertujuan pada pembalasan terhadap si pelaku, sedangkan sanksi tindakan bertujuan untuk memberi perlindungan, perawatan dan pembinaan kepada masyarakat, khususnya bagi pecandu narkotika. Jaminan perlindungan hukum yang diberikan bagi pecandu narkotika diatur melalui Undang-Undang No 35 Tahun 2009 Tentang Narkotika dengan memberikan rehabilitasi baik medis 
maupun rehabilitasi sosial sebagaimana tercantum pada Pasal 54 pada undangundang narkotika yaitu bahwa "pecandu narkotika dan pecandu penyalahguna narkotika wajib menjalani rehabilitasi medis dan rehabilitasi sosial".

\section{DAFTAR PUSTAKA}

Alifia, U, 2008, Apa Itu Narkotika dan Napza, Semarang: PT Bengawan Ilmu

Apriliantin Putri Pamungkas, 2017 "Peran ASEANAPOL dalam Pemberantasan Peredaran Narkoba di Indonesia", Journal of International Relations, Volume 3, Nomor 2,

Hawari, D. 2002. Penyalahgunaan \& Ketergantungan NAZA, Jakarta: FKUI.

I Made Pasek Diantha, 2016, Metodologi Penelitian Hukum Normatif dalam Justifikasi Teori Hukum (Jakarta : Prenada Media Grup).

Mas Candra Dewi, A.A.I, 2012. Perlindungan Hukum Terhadap Korban Penyalahguna Narkotika Dengan Berlakunya Undang Undang No 35 Tahun 2009 Tentang Narkotika, Jurnal Program Studi Magister Hukum Program Magister. Bali: Program Pascasarjana Universitas Udayana.
Wijaya, Wagimin Wira, 2005, Jurnal Intelijen \& Kontra Intelijen volume II/No.07 url: https://media.neliti.com/media/public ations/187604-ID.

\section{Peraturan Perundang-undangan :}

Undang-Undang Nomor 35 Tahun 2009 Tentang Narkotika;

Undang-Undang No 2 Tahun 2002 Tentang Kepolisian Negara Republik Indonesia;

Undang-Undang No 8 Tahun 1976 tentang Pengesahan Konvensi Tunggal Narkotika 1961 beserta Protokol yang mengubahnya

Keppres RI No.17 Tahun 2002 tentang Badan Narkotika Nasional ;

Perpres No. 23 tahun 2010 tentang Badan Narkotika Nasional ;

\section{BIODATA SINGKAT PENULIS}

Damar Bastiar adalah Kepala Seksi Pemberantasan Badan Narkotika Nasional Kota Surabaya. Menyelesaikan Pendidikan Teknik Lingkungan pada Institut Teknologi 10 November Surabaya tahun 2001. Pada saat ini menyelesaikan pendidikan program Magister Hukum, Universitas Narotama Surabaya. 